J. Clin. Chem. Clin. Biochem.

Vol. 16, 1978, pp. 651-655

\title{
Effect of Ascorbic Acid on Oxygen Consumption, Glycolysis and Lipid Metabolism of Diabetic Rat Testis
}

\author{
Ascorbic Acid and Diabetes, I
}

By A. A. Sharaf, A. Kheir El Din, M. A. Hamdy and A. A. Hafeiz

Pharmacology Department, Faculty of Pharmacy and Biochemistry Department, Faculty of Medicine, Cairo University

(Received March 13/June 8, 1978)

Summary: Alloxan diabetes caused a marked stimulation of endogenous oxygen uptake by rat testis tissues. However, the oxygen uptake in the presence of added glucose or pyruvate as substrate was significantly reduced. The ability of the testis tissues to utilize these substrates and to produce lactate was significantly inhibited in the diabetic animals. Alloxan diabetes also increased the levels of cholesterol, cholesterol esters, non-esterified fatty acids, triglycerides and phospholipids in rat testis tissues. Treatment of the diabetic rats with ascorbic acid caused more or less a normalization of all the parameters tested.

\section{Die Wirkung von Ascorbinsäure auf Sauerstoffverbrauch, Glykolyse und Lipidstoffwechsel diabetischer Ratten-Testes}

\section{Ascorbinsäure und Diabetes, 1. Mitteilung}

Zusammenfassung: Alloxan-Diabetes führt zu einer signifikanten Stimulation des endogenen Sauerstoffverbrauchs des Testisgewebes der Ratte. Der Sauerstoffverbrauch wurde in Anwesenheit von Glucose und Pyruvat als Substrate reduziert. Die Fähigkeit des Testisgewebes, diese Substrate zu verwenden und Lactat zu produzieren, wird in diabetischen Tieren signifikant gehemmt. In Rattentestis haben Cholesterin, Cholesterinester, freie Fettsäuren, Triglyceride und Phospholipide infolge des Alloxandiabetes zugenommen. Durch Behandlung mit Ascorbinsäure wurden alle Parameter normalisiert.

\section{Introduction}

Alloxan diabetic effects on male reproduction in the rat are characterized by a decrease in the testis weight and degeneration of the tubular elements $(1,2)$, and marked inhibition of spermatogenesis $(3,4)$.

Foglia (5) observed that fertility began to decline shortly after alloxan treatment and reached negligible level after 6 months. Similar changes were found in male rats rendered diabetic by pancreatectomy $(5,6,7)$.

An increased incidence of impotence $(8,9)$, a decrease in testis weight, and testicular lesion at autopsy have been reported in diabetic human males (10). In addition semen quality, spermatozoa motility, fertility $(11,12)$, and sperm count (13) were depressed.

Deb \& Chatterjee (14) have pointed out that testicular degeneration and arrest of spermatogenesis in alloxan diabetes were primarily due to lack of ascorbic acid in the testis. A marked fall in plasma ascorbic acid level and an increased urinary excretion of this acid has been reported immediately after alloxan injection $(15,16)$ or after subtotal pancreatectomy (17). These deleterious effects caused by alloxan diabetes were corrected by administration of high doses of ascorbic acid (14).

Although the histopathological appearance of alloxan diabetic testis have received great attention, the effects of ascorbic acid on many aspects of carbohydrate and lipid metabolism of diabetic testis have not been fully investigated. This stimulated our interest in the study the effects of ascorbic acid on certain aspects of lipid and carbohydrate metabolism in diabetic rat testis.

\section{Materials and Methods}

Young, male, mature albino rats (Sprague Dawly, Agoza strain) weighing from $180-200 \mathrm{~g}$ were used. The animals were kept under constant environmental and nutritional conditions. The animals were rendered diabetic by a single $i$. p. injection of $150 \mathrm{mg} / \mathrm{kg}$ alloxan (14). 
It is necessary to fast the animals 24 hours before alloxanization. Each diabetic group was divided into two subgroups, one of them received a daily treatment of ascorbic acid $(1.5 \mathrm{~g} / \mathrm{kg}$ body weight) (14). This high dose of ascorbic acid was the dose used by Deb \& Chatteriee (14) to correct the degenerative atrophy of the testis caused by alloxan diabetes.

After 3 weeks of treatment, both of the diabetic and diabetic treated groups were sacrificed.

The diabetic state of the animals was confirmed by the determination of blood sugar 24 hours after alloxan injection and weekly throughout the experimental period. The resistant animals were discarded.

\section{Tissue sampling}

Immediately after killing the animals by decapitation the testis were removed by dissection, blotted between two filter papers and weighed.

Following dissection of tunica albuginca and blood vessels, the tissue was placed on a watch glass chilled on ice and quickly divided. One portion, about $200 \mathrm{mg}$ of tissue was taken and mixed with methanol for subsequent lipid extraction. The remaining part was prepared for measurements of oxygen uptake and other parameters of carbohydrate metabolism.

\section{Carbohydrate metabolism}

\section{Oxygen uptake}

120-150 mg fresh tissue was prepared by teasing apart the tubules and transferred to Warburg flasks containing $3.7 \mathrm{ml}$ of phosphate buffer of $\mathrm{pH} 7.4$ (18). The oxygen uptake was measured by the direct method of Umbreit c.al. (19), in the absence (endogenous oxygen uptake), or presence of substrates. The substrates used were $12 \mathrm{mmol} / 1$ glucose and $5.5 \mathrm{mmol} / 1$ pyruvate. The readings of the manometers were recorded at intervals of 10 minutes.

At the end of the experimental period (one hour) the tissues were removed from the flasks, and the reaction was stopped by addition of $0.2 \mathrm{ml} 100 \mathrm{~g} / 1$ trichloroacetic acid. Centrifugation was carried out for 10 minutes for deproteinization.

For measurement of substrate utilization and lactate production, the difference in glucose or pyruvate concentration in the supernatant fluid at the start and at the end of incubation was calculated. Measurement of glucose was done according to the method of Asatoor \& King (20), pyruvate by the method of Friedmann \& Haugen (21) and lactate by the method of Barker \& Summerson (22).

\section{Extraction and analy sis of lipids}

The total lipids were extracted according to the method of Bligh \& Dyer (23). An aliquot of lipid extract was taken for direct total phospholipid determination $(24,25)$. Another aliquot was used for neutral lipid fractionation. The fractionation was carried out by thin layer chromatography (26).

The system used was that of Muldner et al. (27) and was composed of chloroform/methanol/water (volumes, $70 \mathrm{ml}+$ $30 \mathrm{ml}+5 \mathrm{ml}$ ).

Visualization of the separated lipid spots was carried out by exposure to iodine vapour.

After elution, the cholesterol and its esters (28), triglycerides (29) and nonesterified fatty acids (30) were meạsured.

All the chemicals were of analy tical grade and purchased from E. Merck AG (D-6100 Darmstadt) and BDH chemicals Ltd. (Poole, England). All solvents used were freshly distilled before use; ether was distilled over reduced iron. $2 \%$ methanol was added to the distilled chloroform.

\section{Results}

In alloxan diabetic rats, the testis weight was markedly reduced and reached about $40 \%$, five weeks after alloxanization. Treatment of the diabetic rats for 15 days after alloxanization with ascorbic acid increased the weight of the testes, but they did not completely return to the normal weight.

\section{Carbohydrate metabolism}

As shown in table 1 alloxan-diabetes caused a marked stimulation of endogenous oxygen uptake of the testis tissue, amounting to $33 \%$. However, the $\mathrm{QO}_{2}$ values of the testis tissue were markedly reduced in the presence of glucose or pyruvate as substrates. The ability of testis tissue to utilize these substrates and to produce lactate was significantly inhibited in animals rendered diabetic with alloxan. Treatment with ascorbic acid caused a complete normalization of all parameters tested.

Tab. 1. The effect of diabetes and diabetes treated with ascorbic acid on the testis weight, oxygen uptake ( $\mu \mathrm{l} / \mathrm{h} \cdot \mathrm{g}$ wet weight tissue) in the absence or presence of glucose or pyruvate; glucose or pyruvate utilization and lactate production of the rat testis tissues ( $\mathrm{mg} / \mathrm{g}$, wet weight tissue). Ascorbic acid was given daily in a dose of $1.5 \mathrm{~g} / \mathrm{kg}$ body weight for three weeks. Values are expressed as means \pm S.E.M.

\begin{tabular}{|c|c|c|c|c|c|c|c|c|}
\hline & \multirow{3}{*}{$\begin{array}{l}\text { Testis weight } \\
\text { (g) }\end{array}$} & \multirow{3}{*}{$\begin{array}{l}\text { Endogenous } \\
\text { oxygen uptake } \\
\text { (in absence of } \\
\text { added } \\
\text { substrates) } \\
(\mu \mathrm{l} / \mathrm{h} \cdot \mathrm{g})\end{array}$} & \multicolumn{6}{|c|}{ Oxygen uptake in presence of added substrates } \\
\hline & & & \multicolumn{2}{|c|}{ Glucose (12 mmol/l) } & \multicolumn{4}{|c|}{ Pyruvate $(5.5 \mathrm{mmol} / \mathrm{l})$} \\
\hline & & & $\begin{array}{l}\text { Oxygen } \\
\text { uptake } \\
(\mu \mathrm{l} / \mathrm{h} \cdot \mathrm{g})\end{array}$ & $\begin{array}{l}\text { Glucose } \\
\text { utiliżation } \\
(\mathrm{mg} / \mathrm{g})\end{array}$ & $\begin{array}{l}\text { Lactate } \\
\text { production } \\
(\mathrm{mg} / \mathrm{g})\end{array}$ & $\begin{array}{l}\text { Oxygen } \\
\text { uptake } \\
(\mu \mathrm{l} / \mathrm{h} \cdot \mathrm{g})\end{array}$ & $\begin{array}{l}\text { Pyruvate } \\
\text { utilization } \\
(\mathrm{mg} / \mathrm{g})\end{array}$ & $\begin{array}{l}\text { Lactate } \\
\text { production } \\
(\mathrm{mg} / \mathrm{g})\end{array}$ \\
\hline Control & $\begin{array}{l}2.23 \\
\pm 0.08\end{array}$ & $\begin{array}{l}408 \\
\pm 20.3\end{array}$ & $\begin{array}{l}790 \\
\pm 36.7\end{array}$ & $\begin{array}{l}19.97 \\
\pm 0.82\end{array}$ & $\begin{array}{l}3.38 \\
\pm 0.23\end{array}$ & $\begin{array}{l}731 \\
\pm 29.7\end{array}$ & $\begin{array}{l}6.95 \\
\pm 0.3\end{array}$ & $\begin{array}{l}2.42 \\
\pm 0.25\end{array}$ \\
\hline Diabetic & $\begin{array}{l}1.36^{*} \\
\pm 0.08\end{array}$ & $\begin{array}{l}545^{*} \\
\pm 20.3\end{array}$ & $\begin{array}{l}459 * \\
\pm 18\end{array}$ & $\begin{array}{l}10.58 * \\
\pm 0.89\end{array}$ & $\begin{array}{l}1.78 * \\
\pm 0.15\end{array}$ & $\begin{array}{l}482 * \\
\pm 30\end{array}$ & $\begin{array}{l}3.96^{*} \\
\pm 0.22\end{array}$ & $\begin{array}{l}1.12 * \\
\pm 0.09\end{array}$ \\
\hline $\begin{array}{l}\text { Diabetic } \\
\text { treated with } \\
\text { ascorbic acid }\end{array}$ & $\begin{array}{l}1.91 * * \\
\pm 0.07\end{array}$ & $\begin{array}{l}399 * * \\
\pm 23.83\end{array}$ & $\begin{array}{l}703 * * * \\
\pm 23.4\end{array}$ & $\begin{array}{l}20.57 * * \\
\pm 0.97\end{array}$ & $\begin{array}{l}3.67 * * \\
\pm 0.15\end{array}$ & $\begin{array}{l}732 * * \\
\pm 18.8\end{array}$ & $\begin{array}{l}6.94^{* *} \\
\pm 0.29\end{array}$ & $\begin{array}{l}2.36 * * \\
\pm 0.21\end{array}$ \\
\hline
\end{tabular}

\footnotetext{
Values of each of control, diabetic and diabetic treated with ascorbic acid group are means of 12 male rats.

* Significantly different from the control $(P<0.05)$.

** Significantly different from the diabetic $(P<0.05)$.

*** Significantly different from both control and diabetic $(\mathrm{P}<0.05)$.
} 
Tab. 2. The effects of diabetes and diabetes treated with ascorbic acid on the levels of total phospholipds, cholesterol, cholesterol esters, total cholesterol, non-esterified fatty acids, triglycerides and total lipids of the rat testis tissues. Values are expressed in term of means (mg/g wet weight testis tissue) \pm S.E.M. Ascorbic acid was given daily in a dose of $1.5 \mathrm{~g} / \mathrm{kg}$ body weight for three weeks.

\begin{tabular}{|c|c|c|c|}
\hline & Control & Diabetic & $\begin{array}{l}\text { Diabetic treated } \\
\text { with ascorbic acid }\end{array}$ \\
\hline $\begin{array}{l}\text { Total phospholipids }(\mathrm{mg} / \mathrm{g}) \\
\text { Free cholesterol }(\mathrm{mg} / \mathrm{g}) \\
\text { Cholesterol esters }(\mathrm{mg} / \mathrm{g}) \\
\text { Total cholesterol }(\mathrm{mg} / \mathrm{g}) \\
\text { Non-esterified fatty acids }(\mathrm{mg} / \mathrm{g}) \\
\text { Trigly cerides }(\mathrm{mg} / \mathrm{g}) \\
\text { Total lipids }(\mathrm{mg} / \mathrm{g}) ! !\end{array}$ & $\begin{aligned} 22.73 & \pm 0.8 \\
1.37 & \pm 0.06 \\
0.347 & \pm 0.02 \\
1.7 & \pm 0.05 \\
0.52 & \pm 0.03 \\
3.196 & \pm 0.10 \\
28.15 & \pm 0.86\end{aligned}$ & $\begin{aligned} 35.59 * & \pm 0.68 \\
1.72 * & \pm 0.08 \\
0.975^{*} & \pm 0.05 \\
2.57 * & \pm 0.14 \\
0.886^{*} & \pm 0.04 \\
4.73^{*} & \pm 0.12 \\
43.77^{*} & \pm 0.7\end{aligned}$ & $\begin{array}{ll}25.41 * * & \pm 0.97 \\
1.77 * & \pm 0.07 \\
0.338 * * & \pm 0.03 \\
2.12 * * * & \pm 0.09 \\
0.658 * * * & \pm 0.03 \\
3.455 * * * & \pm 0.12 \\
31.64 * * * & \pm 0.95\end{array}$ \\
\hline
\end{tabular}

The values of each of control, diabetic and diabetic treated with ascorbic acid group are means of 12 male rats.

* Significantly different from the control $(P<0.05)$

** Significantly different from the diabetic $(\mathrm{P}<0.05)$

*** Significantly different from both control and diabetic $(\mathrm{P}<0.05)$

!! The sum of all lipid fractions studied.

\section{Lipid pattern}

Table 2 shows that alloxan diabetes produced a significant rise in rat testicular phospholipids, reaching $56 \%$.

Ascorbic acid treatment significantly reduced testicular phospholipids of the diabetic rats, but the phospholipid level was still higher than that of the control rats.

Alloxan diabetes also increased the levels of cholesterol, cholesterol esters, non-esterified fatty acids, and triglycerides, by $25 \%, 180 \%, 70 \%$ and $47 \%$ respectively.

Treatment of diabetic rats with ascorbic acid caused more or less a normalization of all the lipid fractions tested.

\section{Discussion}

Our results showed that alloxan diabetes markedly reduced the rat testis weight and increased the rate of endogenous oxygen uptake (in the absence of added substrates). These data are in harmony with those reported earlier $(1,2,3,4,31,32)$. The high rate of endogenous respiration of these diabetic aspermatogenic testes could be due to maintenance of the initial oxygen uptake by endogenous substrates. From table 1 it is clear that alloxan diabetes caused a marked reduction in oxygen uptake when either glucose or pyruvate was used as substrate. Furthermore the utilization of the two substrates and the subsequent production of lactate were also inhibited. These effects observed in the diabetic testis might be attributed to one or more of the following: a) loss of spermatocy tes and spermatides, which are the major sites of glucose metabolism (33), b) depression of the key glycolytic enzymes resulting from lack of insulin $(34,35), c)$ lack of ascorbic acid (14) and hence inhibition of certain oxidoreductase enzymes in the glycolytic and citric acid cycle pathways $(36,37,38)$.

These results also indicated that diabetes may produce certain changes in the permeability of the cell and mitochondrial membranes and hence the penetration of the exogenous substrates across these membranes.

This concept supports our findings that endogenous oxygen uptake was reduced on addition of glucose or pyruvate, but was stimulated when these substrates were endogenously present within the cells.

These results revealed that treatment of the diabetic rats with ascorbic acid caused more or less a normalization of the studied parameters of carbohydrate metabolism. This could be a reflection of the histological appearance of mature glucose dependent germ cells in the testis. The importance of ascorbic acid in carbohydrate metabolism is mainly related to its reducing property. Patterson et al (39) observed a decreased level of glutathione in ascorbic acid deficient animals. It is well known that the SH group is essential for a number of enzymes catalyzing the glycolytic and citric acid cycle pathways $(40,41)$. Furthermore BisWas \& Deb (36) reported that succinate dehydrogenase was inhibited in ascorbic acid deficient animals. Thus administration of ascorbic acid to diabetic animals would maintain a high level of the SH group, which was claimed to be lowered by alloxan. Our results showed that diabetes produced a significant rise in all lipid fractions and consequently in the total lipids of the testis. Such an increase could be attributed to impaired development of germinal cells which normally utilize these materials during active spermatogonesis as supplied by Sertoli cells $(42,43,44)$. If it is accepted that testicular lipids arise from serum fatty acids rather than from de novo synthesis within the testis $(45,46)$, the increase in total testicular lipids may be due to increased uptake of fatty acids by the testis in diabetic rats. This seems logical, as it has been reported that in diabetic rats the multienzyme system for acetate incorporation into free fatty acids was markedly lower than the control ones $(47,48,49)$. In 
addition the increment of certain esterified lipid fractions could possibly be explained by an increased rate of esterification of fatty acids to triglycerides, cholesterol esters and phospholipids, since it has been observed that lipids of rat testis show fatty acid incorporation characteristics $(50,51)$. Scott et al $(52$, 53) and Dawson \& Scott (54) reported that phospholipids serve as substrate for spermatozoa during their development and maturation, therefore the rise in total testicular phospholipids in alloxan diabetic rats observed in this study could be explained by a decreased rate of utilization of these compounds as a result of germinal cell depletion (55).

The present investigation showed accumulation of both cholesterol and cholesterol esters in the aspermatogenic diabetic rat testis. This is supported by the finding of Johnson et al (56). The accumulation could result from a decreased rate of androgen biosynthesis, since cholesterol esters are the normal precursor of androgenic steroids $(57,58)$. Another factor that contributes to the elevated level of cholesterol is the increased de novo synthesis from acetyl-CoA. This is in harmony with the finding that testis from rat actively incorporated acetate into free and esterified cholesterol (42).

In the present study, the persistent increased level of non-esterified fatty acids and free cholesterol in the testis of diabetic rat after treatment with ascorbic acid indicates some defects in lipid metabolism. The treated animals being still diabetic, may utilize some of the

\section{References}

1. Lema, B. E., Foglia, V. G. \& Fernandez-Collazo, E. (1965), Rev. Soc. Arg. Biol. 41, 197; c. f. Gomes, W. R. (1970), "The Testis" (Johnson, A. D., Gomes, W. R. \& Vandemark, N.L., eds), Vol. 3, P. 67-138, Academic Press. New York.

2. Hunt, E. L. \& Bailey, D. W. (1961), Acta Endocrinol. 38, $432-440$

3. Chatterjee, A. (1966), Endokrinologie, 50, 11-14.

4. Rosenmann, E., Palti, Z., Teitelbaum, A. \& Cohen, A. M., (1974), Metab. Clin. Exp. 23, 343-348.

5. Foglia, V. G. (1963), in "Perspective in Biology" (Cori, C. F. et al., eds.), p. 158 Elsevier, Amsterdam; c. f. Gomes, W. R. (1970), "The Testis" (Johnson, A. D., Gomes, W. R. \& Vandemark, N.L., eds), Vol. 3, p. 67-138, Academic Press, New York.

6. Foglia, V. G. (1972), Acta. Cient. Venez, 23, 75-82.

7. Foglia, V. G., Rosner, J. M., Catteneo de Peralta Ramos, M. \& Lema, B. E. (1969), Horm. Metab. Res. 1, 72-77.

8. Rubin, A. \& Babbott, D. (1958), J. Am. Med. Assoc. 168, 498-500.

9. Lederer, J. \& Bataille, J. P. (1964), Europ. Rev. Endocrinol. 1, 149-161.

10. Fraley, D. S. \& Totten, R. S. (1968), Metab. Clin. Exp. 17, 896-900.

11. Klebanow, D. \& Macleod, J. (1960), Fertil. Steril. 11, $255-261$.

12. Rubin, A. (1962), Am. J. Obstet. Gynecol. 83, 200-202.

13. Scheffling, K., Federlin, K., Ditschuneit, H. \& Pfeiffer, E. F. (1963), Diabetes 12, 519-527.

14. Deb, C. \& Chatterjee, A. (1963), Experientia 19, 595-596.

15. Siliprandi, N. (1950), Boll. Soc. Ital. Biol. Sper. 26, 793-794. non-esterified fatty acids that they take up, in addition to glucose, for energy production. The significant drop in phospholipid and triglyceride levels, in ascorbic acid treated diabetic rats, may suggest that the incorporation of long chain fatty acids into the two esterified fractions goes at a comparable normal rate. In the testis of diabetic animals the accumulated active acetate, resulting from fatty acid oxidation, would find its way to both the Krebs' cycle and to cholesterol synthesis, after treatment with ascorbic acid, since the fatty acid synthetase system is still inhibited due to lack of insulin (49). The nonsignificant change of free cholesterol in the diabetic rat from that in the testis of ascorbic acid treated animals suggests that the cholesterol synthetase system is still active, even after treatment with ascorbic acid, due to a partial deficiency of insulin.

The considerable drop in cholesterol esters in the testes of diabetic animals after ascorbic acid treatment is a reflection of normalized steroidogenesis, since cholesterol ester is the immediate precursor for testicular steroids $(57,58)$.

Finally it was concluded that diabetes seems to have deleterious effects on the metabolic pathway of the testis as on the other organs, for example liver. However, ascorbic acid did not completely alleviate the ill effects of diabetes in the testis; yet it is advisable to use this vitamin together with the antidiabetic agents to potentiate their good effects on the metabolic pathways in this vital organ.

16. Kauchtschischwili, G. M. (1959), G. Gerontol. 7, 955-956

17. Nelly, B., Catteneo de Peralta Ramos, M., Nelly, G., Calamera, J. C., Ibarra, R. \& Foglia, V. G. (1970), Acta Physiol. Lat. Am., 20, 331-338.

18. Leiderman, B. \& Mancini, R. E. (1968), Proc. Soc. Exp. Biol. Med. 128, 818-821.

19. Umbreit, W. W., Burris, R. H. \& Stauffer, J. F. (1964), Manometric techniques, 4 th printing, p. 163-168. Burgess Pub. Co. Minneapolis.

20. Asatoor, A. M. \& King, E. J. (1954), Biochem. J. 56, Proc. xliv.

21. Friedemann, T. E. \& Haugen, G. E. (1943), J. Biol. Chem. $147,415-442$.

22. Barker, S. B. \& Summerson, W. H. (1941), J. Biol. Chem. $138,535-554$.

23. Bligh, E. G. \& Dyer, W. J. (1959), Can. J. Biochem. Physiol. 37, 911-917.

24. Connerty, H. V., Briggs, A. R. \& Eaton, E. H. Jr. (1961), Clin. Chem. 7, 37-53.

25. Fiske, C. H. \& Subbarow, Y. (1925), J. Biol. Chem. 66, $375-400$.

26. Webster, G. R. (1967), Biochem. J. 102, 373-380.

27. Webster, D. (1962), Clin. Chim. Acta 7, 277-284.

28. Fletcher, M. J. (1968), Clin. Chim. Acta 22, 393-397.

29. Foster, L. B. \& Dunn, R. T. (1973), Clin. Chem. 19, 338340.

30. Duncombe, W. G. (1963), Biochem. J. 88, 7-10.

31. Tepperman, J., Tepperman, H. M. \& Dick, H. J. (1949), Endocrinology, 45, 491-503.

32. Steinberger, E. \& Wagner, C. (1961), Endọcrinology, 69, $305-311$. 
33. Free, M. J. (1970), The Testis (Johnson A. D., Gomes, W. R. \& Vandemark, N. L., eds), Vol. 2, p. 125-192. Academic Press, New York.

34. Weber, G. \& Singhal, R. L. (1965), Life Sci. 4, 1993-2002.

35. Weber, G., Stamm, N. B. \& Fischer, E. A. (1965), Science, 149, 65-67.

36. Biswas, N. M. \& Deb, C. (1967), Acta Histọchem. 27, 85-89.

37. Ganguli, N. C. \& Banerjee, A. B. (1961), J. Biol. Chem. $236,979-982$.

38. Takeda, Y. \& Hara, M. (1955), J. Biol. Chem. 214, 657670.

39. Patterson, J. W., Lazarow, A. \& Levey, S. (1949), J. Biol. Chem. 177, 197-204

40. Jocelyn, P. C. (1972), in "Biochemistry of the SH group", p. 135-170, Academic Press London, New York.

41. Hopkins, F. G., Morgan, E. J. \& Lutwak-Mann, C. (1938), Biochem. J. 32, 1829-1847.

42. Johnson, A. D. (1970), in "The Testis" (Johnson A. D., Gomes, W. R. \& Vandemark, N. L., eds). Vol. 2, p. 193258, Academic Press New York.

43. Long, M. E. \& Engle, E. T. (1952), Ann. N. Y. Acad. Sci. $55,619-741$.

44. Lacy, D. \& Lofts, B. (1965), Proc. Roy. Soc. London Ser. B. $162,188-197$

45. Goswami, A. \& Williams, W. L. (1967), Biochem. J. 105, 537-543.
46. Swell, L. \& Law, M. D. (1967), Proc. Soc. Exp. Biol. Med. 124, 739-741.

47. Whorton, A. R. \& Coniglio, J. G. (1975), Lipids 10, 783789.

48. Haeffner, E. W. \& Privett, O. S. (1975), Lipids 10, 814-817.

49. Wieland, O., Neufeldt, I., Numa, S. \& Lynen, F. (1963), Biochem. Z. 336, 455-459.

50. Robert, R. L. \& Spaziani, E. (1968), J. Reprod. Fertil. 15, 365-372.

51. Webster, G. R. (1965), Biochem. Biophys. Acta 98, 512-519.

52. Scott, T. W., Dawson, R. M. C. \& Rowland, I. W. (1963), Biochem. J. 87, 507-512.

53. Scott, T. W., Voglmayr, J. K. \& Setchell, B. P. (1967), Biochem. J. 102, 456-461.

54. Dawson, R. M. C. \& Scott, T. W. (1964), Nature 202, 292293.

55. Butler, W. R., Johnson, A. D., Gomes, W. R. \& VanDemark, N. L. (1967), J. Dairy Sci. SO, 1005-1006.

56. Johnson, A. D., VanDemark, N. L., Gomes, W. R., Butler, W. R. \& Hodgen, G. D. (1967), Fed. Proc. Fed. Am. Soc. Exp. Biol. 26, 645.

57. Bartke, A. (1971), J. Endocrinol. 49, 317-324.

58. Bartke, A., Musto, N., Caldwell, B. V. \& Behrman, H. R. (1973), Prostaglandins 3, 97-104.

Dr. A. A. Sharaf

Dr. A. Kheir El Din Pharmacology Department

Faculty of Pharmacy

Riyadh University

Riyadh

Saudi Arabia 
